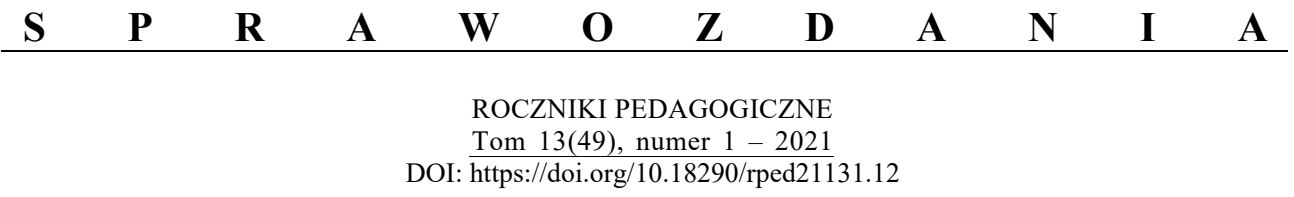

\author{
ANNA BADORA \\ Instytut Pedagogiki KUL \\ e-mail: rudaanna89@gmail.com \\ ORCID: https://orcid.org/000-0002-3797-8489
}

\title{
SPRAWOZDANIE Z JESIENNYCH \\ WARSZTATÓW METODOLOGICZNYCH \\ SEKCJI PEDAGOGIKI CHRZEŚCIJAŃSKIEJ \\ KOMITETU NAUK PEDAGOGICZNYCH \\ POLSKIEJ AKADEMII NAUK I ZESPOŁU WSPIERAJĄCEGO
}

W dniach od 18 do 20 września 2020 roku, w Kazimierzu Dolnym, odbyły się w ramach prac Sekcji Pedagogiki Chrześcijańskiej Kazimierskie Warsztaty Metodologiczne 2020. Ich uczestnikami byli nie tylko członkowie sekcji, ale także jej sympatycy. Na tegorocznych warsztatach podjęto temat: „Karola Wojtyły/Jana Pawła II metoda analizy personalistycznej”.

Sesja wprowadzająca w obrady została zatytułowana: Personalistyczne podejścia badawcze Karola Wojtyty/Jana Pawła II w odniesieniu do teorii i praktyki działalności ludzkiej (w tym wychowawczej). Jako pierwszy głos zabrał Przewodniczący Sekcji - ks. prof. dr hab. Marian Nowak, reprezentant Katolickiego Uniwersytetu Lubelskiego Jana Pawła II. Ksiądz Profesor w swoim wystąpieniu przedstawił szczegółową charakterystykę zróżnicowanych podejść personalizmu do przedmiotu badań: egzystencjalnego, dialogicznego, dialektycznego i fenomenologicznego. Referat ujawnił wielość personalistycznych dróg pozna(wa)nia ludzkiej osoby. Jako kolejny referent, swoje analizy zaprezentował prof. Uniwersytetu Śląskiego, dr hab. Marek Rembierz, podejmując temat: Osoba - teoria - praxis. Karola Wojtyly metoda analizy personalistycznej a rozwój refleksji antropologicznej i pedagogicznej o inspiracji personalistycznej. Prelegent podjął trud wskazania i interpretacji kategorii kluczowych dla metody analizy personalistycznej Wojtyły. Odniósł je do charakterystyki rozwoju antropologii i pedagogiki, czerpiących inspiracje z personalizmu. 
W kolejnym dniu warsztatów podjęto temat: Obszary badawcze poddawane analizie przez Karola Wojtyłę/ Jana Pawła II. W drugiej sesji spotkania ukazano miejsca i obszary badań pedagogiki personalistycznej z odniesieniami do twórczości Karola Wojtyły/ Jana Pawła II. Referat wprowadzający wygłosił ks. prof. ndzw. dr hab. Jan Śledzianowski, związany z Uniwersytetem Jana Kazimierza w Kielcach oraz Wyższą Szkołą Biznesu i Przedsiębiorczości w Ostrowcu Świętokrzyskim. W swoim wystąpieniu, nawiązując do autorskiej książki: $Z$ polskiej rodziny wyszedt i miłościa ogarną cały świat. W stulecie urodzin Świętego Jana Pawła II, wskazywał na fundamentalną rolę najbliższej rodziny (matki, ojca, brata) Karola Wojtyły w kształtowaniu chrześcijańskiej pedagogii i pedagogiki Jana Pawła II. Kolejna prelegentka - prof. UJK, dr hab. Anna Kieszkowska, zwróciła uwagę na to jak, według Karola Wojtyły, wyjątkowy i niepowtarzalny charakter ma istnienie osobowe. Prof. UKSW, dr hab. Witold Starnawski, łącząc się zdalnie z pozostałymi uczestnikami wydarzenia, przedstawił niezwykle istotne uwagi na temat metody personalistycznej Karola Wojtyły/Jana Pawła II. Wskazał on na konieczność uwzględnienia w jej charakterystyce wszystkich obszarów twórczości i życiowego doświadczenia wybitnego Polaka: literatury pięknej, aktorstwa, teologii, filozofii i duszpasterstwa.

Rozważania trzeciej sesji warsztatów dotyczyły „doboru metody i wspólnoty naukowej w badaniach". Pierwszym prelegentem w tej sesji był prof. Akademii Jana Długosza w Częstochowie, dr hab. Wiesław Wójcik, który za pomocą metody analizy personalistycznej Karola Wojtyły/Jana Pawła II podjął próbę ukazania istoty fenomenu wspólnoty naukowej. Następnie ks. prof. UJK, dr hab. Sławomir Chrost dokonał charakterystyki „metody adekwatnej” w antropologii Karola Wojtyły. Z kolei profesor Akademii Jana z Paradyża w Gorzowie Wlkp., dr hab. Andrzej Jakub Sowiński, przedstawił „niektóre swoistości badań pedagogicznych prowadzonych metodą analizy personalistycznej”. Uwypuklił przy tym niezwykle istotny dla pedagogiki praktyczny wymiar teorii wychowania.

Czwarta sesja spotkania poświęcona była zagadnieniom skoncentrowanym wokół tematu: Szkolna edukacja personalistyczna w świetle nauczania Jana Pawła II. Pierwszy referat zaprezentowali: Pani prof. dr hab. Krystyna Chałas oraz ks. prof. KUL, dr hab. Adam Maj. Prelegenci przedstawili analizy wskazujące, iż projekty edukacyjne mogą stać się drogą do zgłębiania (lepszego rozumienia) nauczania Jana Pawła II. Kolejny referat stanowił swoistą kontynuację, podjętych przez pierwszych prelegentów zagadnień. Panie: dr Marta Buk-Cegiełka oraz dr Anna Badora wskazały na konkretne możliwości realizacji nauczania Jan Pawła II w procesie lekcyjnym.

W trzecim dniu obrad analizom poddano zagadnienie: Pedagogiczny personalizm w obliczu wyzwań współczesności - jego kompetencje i doświadczenia. Odbywająca się wtedy piąta sesja, zatytułowana Teoretyczny i praktyczny wymiar edukacji personalistycznej, zawierała dwa referaty. W pierwszym siostra prof. Akademii Ignatianum, dr hab. Anna Walulik CSFN, przedstawiła praktyczny wymiar ,paradygmatu podmiotowo-partycypacyjnego w badaniach w działaniu”. Następnie prof. UJK Tadeusz 
Sakowicz wskazywał, na podstawie metody analizy personalistycznej, na „ojcostwo” Jana Pawła II wobec religii świata. W sesji szóstej refleksji poddano kwestię: Osoba jako punkt wyjścia personalistycznej edukacji i pedagogiki. Pierwsza referentka Pani prof. KUL, dr hab. Alina Rynio, zwróciła uwagę na ontologiczny wymiar człowieka jako podstawę integralnego wychowania osoby w nauczaniu Karola Wojtyły/ Jana Pawła II. Wieńcząc całe spotkanie, ks. prof. dr hab. Marian Nowak przedstawił „introspekcję osoby z pozycji pedagogiki personalistycznej”. Wszystkim sesjom warsztatowym towarzyszyły żywe dyskusje prelegentów i ich słuchaczy.

Na zakończenie sesji przeprowadzono dyskusję, po której dokonano podsumowania obrad, przedstawiono tematy i plany pracy Zespołu na rok 2020/21.

\author{
ALINA RYNIO \\ Instytut Pedagogiki KUL \\ e-mail:memor@kul.pl \\ ORCID: https://orcid.org/0000-0003-4113-7620 \\ DOI: https://doi.org/10.18290/rped21131.13
}

\title{
SPRAWOZDANIE Z POSIEDZENIA SEKCJI \\ PEDAGOGIKI CHRZEŚCIJAŃSKIEJ \\ KOMITETU NAUK PEDAGOGICZNYCH POLSKIEJ AKADEMII NAUK
}

W dniu 21 października 2020 r., zgodnie z przyjętym uprzednio harmonogramem, pomimo panującej pandemii odbyło się kolejne posiedzenie Sekcji Pedagogiki Chrześcijańskiej działającej pod Patronatem KNP PAN. Było ono możliwe dzięki wykorzystaniu platformy uniwersyteckiej i rozwiązaniom technicznym za pośrednictwem aplikacji MS TEAMS.

Tradycyjnie o godz. 9.00 odprawiona została Msza św., celebrowana przez ks. prof. Mariana Nowaka w intencji wszystkich członków SPCH. Tym razem ci, którzy chcieli w niej uczestniczyć, łączyli się on-line z Kaplicą na ul. Bernardyńskiej 7 w Lublinie.

O godz. 10.00 rozpoczęło się posiedzenie Sekcji Pedagogiki Chrześcijańskiej poświęcone jakże ważnej kwestii, jaką jest: Nowy humanizm św. Jana Pawła II i jego znaczenie dla wspótczesnej pedagogiki. Do analizowania tej problematyki (przeniesionej ze względu na pandemię z maja 2020 r.) wprowadzali uprzednio zgłoszeni prelegenci reprezentujący różne środowiska akademickie w Polsce. W trakcie posie- 